\title{
Growth Response of Peppermint (Mentha piperita L.) Stem Cuttings on Several Composition of Planting Media
}

\author{
Rio Ramadhan Butar Butar, Ferry Ezra Sitepu, and Yaya Hasanah \\ Department of Agrotechnology, Faculty of Agriculture, Universitas Sumatera Utara, Indonesia
}

\begin{abstract}
Planting media is one of the keys to success in cultivating peppermint to produce the optimal growth. The objective of the research is to determine the growth response of peppermint stem cutting on composition of planting media. The research was conducted at the research field of the Faculty of Agriculture, Universitas Sumatera Utara, Medan on August to October 2017 using non factorial randomized block design consisted of composition of planting media (top soil ; top soil + biochar (3:1); top soil + chicken manure (3:1); top soil + empty fruit bunches of palm oil compost (3:1); top soil + empty fruit bunches of palm oil compost + chicken manure $(2: 1: 1)$; top soil + biochar + chicken manure (2:1:1); top soil + biochar + empty fruit bunches of palm oil compost $(2: 1: 1)$. The results show that the composition of planting media was significantly effect of the percentage of cutting grows, number of shoots, length of shoots, root volume and number of leaves. Top soil: EFB of palm oil $(3: 1)$ the best treatment because it increases the percentage of cutting growth, root volume, dry weight and root dry weight.
\end{abstract}

Keywords: peppermint, planting media, stem cutting

Received 20 July 2018 | Revised 06 August 2018 | Accepted 08 August 2018

\section{Introduction}

Peppermint (Mentha piperita L.) is an annual herb that belongs to the Lamiaceae family. The stem and leaves of peppermint are able to produce the peppermint oil called menthol [1]. Menthol is an essential oil obtained from the distillation of peppermint. Peppermint oil has not been widely produced in Indonesia therefore menthol is a future commodity that can be developed in Indonesia. In international market menthol widely used as raw material in food, beverage and pharmaceutical industries as antiseptic, balsam, toothpaste, inhaler, breath fragrance, perfume, even around 1920 menthol began to be used as a flavor in the tobacco industry [2].

\footnotetext{
*Corresponding author at: Department of Agrotechnology, Faculty of Agriculture, Universitas Sumatera Utara, Jl. Prof A. Sofyan No. 3, Kampus USU, Medan, Indonesia

E-mail address: yaya@usu.ac.id
} 
The high demand for peppermint oil cannot be fulfilled by domestic production so that the government imports. The problem in peppermint cultivation is the limited availability of peppermint seeds so that the seed needs are not sufficient. In pioneering the development of peppermint cultivation requires good planting materials, efficient against time and low cost.

The peppermint plant is propagated vegetatively through stem cuttings. Vegetative growth of peppermint can be encouraged by using appropriate planting medium. Therefore, this study aims to determine the growth of stem cuttings peppermint on various composition of planting media.

\section{Materials and Methods}

\subsection{Study Area and Materials}

This research was conducted at the research field of Faculty of Agriculture, Universitas Sumatera Utara, Medan, located \pm 32 meter above sea level, on August to October 2017. The materials used were cutting stem of peppermint, $15 \mathrm{~cm}$ x $20 \mathrm{~cm}$ polybags, top soil, empty fruit bunches (EFB) of palm oil compost, biochar, chicken manure. The tools were hoe, sieve, ruler, hand sprayer, scales, bucket, scissors and cutter.

\subsection{Procedures}

This research applied non factorial Randomized Block Design (RBD) consisted of M1 = top soil; M2 = top soil + biochar (3:1); M3 = top soil + chicken manure (3:1); M4 = top soil + empty fruit bunches (EFB) of palm oil compost (3:1); M5 = top soil + EFB of palm oil compost + chicken manure $(2: 1: 1) ;$ M6 $=$ top soil + biochar + chicken manure $(2: 1: 1) ;$ M7 = top soil + biochar + EFB of palm oil compost $(2: 1: 1)$.

Planting media preparation is carried out according to treatment. The planting medium is mixed by volume using a bucket with a dose according to treatment. Furthermore, the planting medium was put into $2 \mathrm{~kg}$ polybags. Preparation of cutting materials is done by arranging from a healthy peppermint plant, then cut the cuttings of the 5-section stem with a size of approximately $12 \mathrm{~cm}$. The stem cuttings are planted with the base of the stem embedded in the ground about $2.5 \mathrm{~cm}$. Each cut of the stem that has been planted is given a lid using transparent plastic as a whole in the planting area. The lid is opened after the plant is 2 weeks old. Watering is done every day, namely in the morning or evening. Weeding is done manually periodically once a week. Caterpillar and insect control is carried out using an insecticide that is active in deltrametrin at a dose of $1 \mathrm{ml} / 1$ of water. The parameters observed were percentage of cutting growth, root volume, root dry weight and shoot dry weight. Observation of percentage of cutting growth is done at 12 WAP, calculated by the formula: 
Observation root volume was carried at 12 WAP. Root volume is the difference from the volume of water that rises after the root is inserted into a measuring glass with the volume of water before the root is inserted.

\subsection{Data Analysis}

The data were analyzed using a significant variance analysis followed by a Duncan's Multiple Range Test with $\mathrm{p}=5 \%$.

\section{Results and Discussion}

\subsection{Percentage of Cutting Growth}

Percentage of cutting growth of peppermint on treatment of composition of planting media can be seen in Table 1. The result showed that the highest percentage of cutting growth is the composition of planting media $\mathrm{M}_{2}$ (top soil + biochar = 3:1) and $\mathrm{M}_{4}$ (top soil: $\mathrm{EFB}$ palm oil = 3 : 1) compared to $M_{3}$ (top soil: chicken manure $=3: 1$ ). This indicated that biochar and EFB of palm oil were essential in the growth of stem cuttings of peppermint.

Biochar used in this study was from rice husks, can help the availability of nutrients that can be absorbed by plants. This is supported by Kurniawan et. al. [3] and Gani [4] that biochar provides a good habitat for soil microbes such as bacteria that help in nutrient decomposition so that nutrients can be absorbed by plants. Biochar in the long time, able to increase water holding capacity and nutrients available to plants and does not interfere with carbon-nitrogen balance. The application of biochar into the soil may increase the availability of major cations, $\mathrm{P}$ and $\mathrm{N}$ concentrations in the soil. Increased cation exchange capacity and soil $\mathrm{pH}$ can increase up to $40 \%$. Biochar can address some of the soil problems in the cultivation process and provide additional options for managing the soil.

The addition of EFB of palm oil also increased the percentage of cutting growth because EFB of palm oil compost contains nutrients that require crops such as $\mathrm{K}, \mathrm{P}, \mathrm{Ca}, \mathrm{Mg}, \mathrm{C}$ and N. EFB of palm oil compost can enrich the properties that are in the soil and capable physical, chemical and biological soil. This is supported by Rosenani et al. [5] which states that the organic material contained will increase the activity in assisting the decomposition process. Organic materials contained in EFB of palm oil can improve air binding capacity, as well as treat aeration and drainage of the soil. The $\mathrm{N}$ element contained in EFB of palm oil compost helps increase the number of live cuttings in peppermint. 


\subsection{Root Volume}

Root volume of stem cutting of Peppermint on treatment of composition of planting media can be seen in Table 1 . The treatment of composition of planting media $\mathrm{M}_{4}, \mathrm{M}_{5}$ and $\mathrm{M}_{7}$ increased the root volume when compared to $M_{1}$ but not significantly different from $M_{2}, M_{3}$ and $M_{6}$. This indicated that the addition of organic materials in the form of EFB of palm oil, chicken manure and biochar increase porosity so that facilitate the growth of root and nutrient absorption. Han [6] supported that organic manure has multiple benefits due to the balanced supply of nutrients, including micronutrients, increased soil nutrient availability due to increased soil microbial activity, the decomposition of harmful elements, soil structure improvements and root development, and increased soil water availability.

Table 1. Percentage of Cutting Growth and Root Volume of Stem Cutting of Peppermint on Treatment of Planting Media Composition

\begin{tabular}{ccc}
\hline $\begin{array}{c}\text { Treatment } \\
\text { (Top soil : biochar : EFB palm oil : chicken } \\
\text { manure) }\end{array}$ & $\begin{array}{c}\text { Percentage of } \\
\text { cutting grows (\%) }\end{array}$ & $\begin{array}{c}\text { Root volume of stem } \\
\text { cutting (ml) }\end{array}$ \\
\hline $\mathrm{M}_{1}(1: 0: 0: 0)$ & $85 \mathrm{a}$ & $0.25 \mathrm{~b}$ \\
$\mathrm{M}_{2}(3: 1: 0: 0)$ & $90 \mathrm{a}$ & $1.38 \mathrm{ab}$ \\
$\mathrm{M}_{3}(3: 0: 0: 1)$ & $40 \mathrm{~b}$ & $1.88 \mathrm{ab}$ \\
$\mathrm{M}_{4}(3: 0: 1: 0)$ & $90 \mathrm{a}$ & $4.75 \mathrm{a}$ \\
$\mathrm{M}_{5}(2: 0: 1: 1)$ & $65 \mathrm{ab}$ & $3.88 \mathrm{a}$ \\
$\mathrm{M}_{6}(2: 1: 0: 1)$ & $55 \mathrm{ab}$ & $3.25 \mathrm{ab}$ \\
$\mathrm{M}_{7}(2: 1: 1: 0)$ & $75 \mathrm{ab}$ & $4.63 \mathrm{a}$ \\
\hline
\end{tabular}

Notes: Different letters at the same colomn represent significant differences at Duncan's Multiple Range Test $(\mathrm{p}=0.05)$

\subsection{Root and Shoot Dry Weight}

Root dry weight and shoot dry weight of stem cutting of peppermint on treatment of composition of planting media can be seen in Table 2. Based on Table 2 it can be seen that the composition of $\mathrm{M}_{7}$ growing media tends to produce the highest root dry weight, whereas $\mathrm{M}_{1}$ produces the lowest root dry weight. The highest shoot dry weight found in $\mathrm{M}_{3}$ treatment was not significantly different from $\mathrm{M}_{4}$ and $\mathrm{M}_{7}$, but was significantly different with $\mathrm{M}_{1}$. This indicated that the addition of organic materials such as EFB of palm oil and chicken manure in planting medium will increase root dry weight and shoot dry weight.

The positive effects of compost in raising seedlings include changes in the soil physical properties, exchange and buffering capacities, and being a direct source of nutrients for plants. Previous study by Aisueni and Omoti [7] in Nigeria found that application of composted EFB with POME at rate of $150 \mathrm{~g}$ per polybag increased seedling dry matter weight up to $71 \%$ at the main nursery stage.

Adding compost also improved the chemical properties of the growing medium as shown by various studies, which reported the ability of compost to reduce soil acidity [8-9]. This could be 
attributed to the presence of complex humic acid in compost [11] which provided binding sites for exchangeable bases and decreased the availability of polycations like $\mathrm{Fe} 2+$ and $\mathrm{Al}+[10]$. Addition of composted agricultural waste had been reported to significantly improve root growth [11]

Table 2. Root dry weight and shoot dry weight of Stem Cutting of Peppermint on treatment of composition of planting media

\begin{tabular}{ccc}
\hline $\begin{array}{c}\text { Treatments } \\
\text { (Top soil : biochar : EFB palm oil : chicken } \\
\text { manure) }\end{array}$ & $\begin{array}{c}\text { Root dry weight } \\
\mathbf{( g )}\end{array}$ & $\begin{array}{c}\text { Shoot dry weight } \\
\text { (g) }\end{array}$ \\
\hline $\mathrm{M}_{1}(1: 0: 0: 0)$ & 0.14 & $0.39 \mathrm{~b}$ \\
$\mathrm{M}_{2}(3: 1: 0: 0)$ & 0.29 & $1.05 \mathrm{~b}$ \\
$\mathrm{M}_{3}(3: 0: 0: 1)$ & 0.39 & $9.50 \mathrm{a}$ \\
$\mathrm{M}_{4}(3: 0: 1: 0)$ & 0.73 & $8.29 \mathrm{a}$ \\
$\mathrm{M}_{5}(2: 0: 1: 1)$ & 0.70 & $9.28 \mathrm{a}$ \\
$\mathrm{M}_{6}(2: 1: 0: 1)$ & 0.31 & $7.23 \mathrm{ab}$ \\
$\mathrm{M}_{7}(2: 1: 1: 0)$ & 0.80 & $7.90 \mathrm{a}$ \\
\hline
\end{tabular}

Notes: Different letters at the same colomn represent significant differences at Duncan's Multiple Range Test $(\mathrm{p}=0.05)$

\section{Conclusion}

Planting medium composition of top soil: EFB of palm oil (3:1) is the best treatment because it increases the percentage of cutting growth, root volume, shoot dry weight and root dry weight.

\section{REFERENCES}

[1] E. Hadipoentyanti, Pedoman Teknis Teknologi Tanaman Rempah dan Obat, Balai Penelitian Tanaman Rempah dan Obat Kementerian Pertanian, 2012.

[2] M. D. Sokovie, J. Vukojevic, P. D. Marin, D. D. Brkie, V. Vajs, and L. J. van Griensven, "Chemical composition of essential oil of Thymus nad Metha species and their anti fungal activities," Molecules, vol 1, no. 1, pp. 238-249, 2009.

[3] A. Kurniawan, B. Haryono, M. Baskara and S. Y. Tyasmoro, "Pengaruh penggunaan biochar pada media tanam terhadap pertumbuhan bibit tanaman tebu (Saccharum officinarum L.)," Jurnal Produksi Tanaman vol. 4, no. 2, pp.153-160, 2016.

[4] A. Gani, "Potensi Arang Hayati "Biochar" sebagai Komponen Teknologi Perbaikan Produktivitas Lahan Pertanian,” Iptek Tanaman Pangan, vol. 4, no. 1, pp. 33-48, 2009.

[5] A. B. Rosenani, R. Rovica, P. M. Cheah, and C. T. Lim, "Growth Performance and Nutrient Uptake of Oil Palm Seedling in Prenursery Stage as Influenced by Oil Palm Waste Compost in Growing Media," International Journal of Agronomy, vol. 2016, pp. 1-8, 2016.

[6] S. H. Han, J. Y. An, J. Hwang, S. B. Kim and B. H. Park, "The effects of organic manure and chemical fertilizer on the growth and nutrient concentrations of yellow poplar (Liriodendron tulipifera Lin.) in a nursery system," Journal Forest Sciece and Technology, vol. 12, no. 3, pp. 137-143, 2016.

[7] N. O. Aisueni and U. Omoti, "The role of compost in sustainable oil palm production, in Cutting-Edge Technologies for Sustained Competitiveness," in Proceedings of the 2001 PIPOC International Palm Oil Congress, Agriculture Conference, 2001, pp. 536-541. 
[8] P. J. Valarini, G. Curaqueo, and A. Seguel, "Effect of compost application on some properties of a volcanic soil from central South Chile," Chilean Journal of Agricultural Research, vol. 69, no. 3, pp. 416-425, 2009.

[9] J. Butler and J. P. Muir, "Dairy manure compost improves soil and increases tall wheatgrass yield," Agronomy Journal, vol. 98, no. 4, pp. 1090-1096, 2006.

[10] E. P. Jouquet, E. Bloquel, and T. T. Doan, "Do compost and vermicompost improve macronutrient retention and plant growth in degraded tropical soils?", Compost Science and Utilization, vol. 19, no. 1, pp. 15-24, 2011.

[11] D. Budianta, P. K. S. A. Halim, N. S. Bolan, and R. J. Gilkes, "Palm oil compost reduces aluminum toxicity thereby increases phosphate fertilizer use efficiency in ultisols," in Proceedings of the 19th World Congress of Soil Science, 2010, pp. 221-223. 